\title{
THE EFFECT OF KNOWLEDGE MANAGEMENT ON INVESTOR BEHAVIOUR
}

\author{
Mochammad Nugraha Reza Pradana ${ }^{1}$, Afrianti Elsye Vanomy ${ }^{2}$ \\ Universitas Universal, Indonesia ${ }^{12}$ \\ rezapradana7@gmail.com ${ }^{1}$, yanti elva@yahoo.com ${ }^{2}$
}

\begin{abstract}
Market efficiency will be achieved if investors can think rationally. Therefore, knowledge management is needed to create rational investor behaviour in the Indonesian Capital Market. This study aims to analyze the role of knowledge management on investor behaviour. This type of research is quantitative research. The population of this study is 211 investors who are registered at the Investment Gallery Universal University. The sample in this study amounted to 55 investors with the random sampling technique. The data analysis technique used is the Structural Equation Model (SEM) with SmartPLS version 3.0. The results showed that Knowledge Management has a significant influence on Investor Behaviour.
\end{abstract}

Keywords: Investor Behaviour, Knowledge Management

\section{INTRODUCTION}

The Indonesian Capital Market has experienced development from year to year. Data from PT. Kustodian Sentral Efek Indonesia (KSEI) states that the number of capital market investors continues to grow. As of June 2019, Indonesian Capital Market Investors have reached $1,971,213$, this figure has increased $44 \%$ compared to the previous year. The growing quantity of investors is dominated by local ownership, namely as much as $54.95 \%$, and the rest by foreign investors. The achievement of local investor growth is certainly the success of the Self Regulatory Organization (SRO) in developing the Indonesian Capital Market. On the other hand, the growing quantity of investors must be accompanied by quality. The quality of investors can be seen by their effectiveness in achieving investor goals in the capital market.

As is well known, the main objective of investors in the capital market profits in the form of dividends or capital gains. The achievement of investors' objectives in the capital market has encountered various challenges, especially for local investors. Local investors are still considered to be heavily influenced by foreign investors. Karo said that local investors had experienced panic over the fall of 2 (two) large share prices, namely shares of PT. Unilever (UNVR) and shares of PT. Sampoerna (HMSP) in July 2019. This panic was initiated by foreign investors who slammed the two share prices. The sale of UNVR and HMSP shares by foreign investors was immediately followed by a sell-off by local investors. Foreign investors responded quickly to this massive selling action to buy back the two shares.

The behaviour of local investors can be explained by Over Reacting Theory. The theory of overreacting can be described when investors are optimistic when the market is bullish and become very pessimistic when there is a market slump (bearish)(Hong \& Stein, 1999). Also, such a massive sell-off could be explained by (Nofsinger, 2002) regarding the social interaction theory which explains that the action can occur because of the interaction between investors and other investors which results in emotional influences on one or more investors. Such behaviour will certainly be far from creating an efficient market because it tends to reflect irrational investor behaviour, namely behaviour that ignores other available information, whereas according to Agustin all actions of investors in the capital market are assumed to pay attention to all information in the market and behave rationally. Information 
obtained by investors must be able to be processed properly.

According to (Shahzad, 2013) The concept of rational investors in decisionmaking theory means that in making decisions, the chosen action is the one that produces the highest utility. A rational investor will analyze the investment decision-making process. The analysis is carried out, among others, by studying the company's financial statements, as well as evaluating the company's business performance to make investment decisions that will provide optimal satisfaction scores.

Generally, in the investment decision-making process, accounting information has relevant value because accounting information is statistically related to market value (Puspitaningtyas, 2013). The value relevance of accounting information is defined as the ability to explain firm value which is directed to investigate the empirical relationship between stock market value and various accounting information figures intended to assess the usefulness of these numbers in the company's fundamental valuation.

Investment objectives can be achieved if investors are right in making investment decisions so that these decisions have considered the expected level of return and also the risks to be faced.

According to (Christanti et al., 2011) There is some information needed by investors, namely 1) Neutral Information, namely information that comes from outside which shows impartial information, 2) Accounting Information, which is information related to the company's financial statements, 3) Self Image, namely information related to the assessment of the company, 4) Classic, namely information about opening share prices, dividends and taxes, 5) Advocate Recommendation, namely information from professionals, 6) Social Relevance, namely information about the company's existence on the stock exchange, and 7)
Personal Financial, namely information based on experienced investors. Information is discovered, selected, organized, and transferred to achieve investors' goals. The information processing process is called knowledge management (Rahimli, 2012).

Knowledge management is a process and/or practice in creating, obtaining, capturing, sharing, and using knowledge to improve learning and organizational performance (Armstrong \& Mahmud, 2008). Thus, knowledge management can be interpreted as a strategy or solution to the problems of life in the context of humans as lifelong learners. Knowledge management is expected to be a solution to help an individual in an organization to have equal knowledge, then with that equal knowledge, it can help develop the organization. (Veer Ramjeawon \& Rowley, 2017) states that the knowledge management process itself regulates the creation, dissemination, and utilization of knowledge to meet organizational goals.

From the background that has been described, the purpose of this study is to determine the effect of knowledge management on investor behaviour.

\section{METHODS}

The place of research in this study is Kresna Sekuritas Batam Branch which is located at the Investment Gallery in Universitas Universal.

The population of this research is all active stock investors listed in the Investment Gallery, namely 211 (two hundred and eleven) investors. Samples were taken as many as 55 (fifty-five) stock investors with the sampling technique using random sampling techniques, according to Sugiyono where this technique is a sampling technique from members of the population which is done randomly without paying attention to the strata in the population. 
The technique of collecting data using a questionnaire. The Knowledge Management variable and investor behaviour each have 6 (six) indicators which are made into 6 (six) statement items. The six statement items were answered by the respondent with a value of 1 (Strongly Disagree) to 6 (Strongly Agree).

This research uses data analysis techniques SEM (Structural Equation Model) SmartPLS version 3.0. The planning analysis method used in this research includes descriptive statistical analysis and inferential statistical analysis. The test instruments used in this study were validity and reliability tests. A questionnaire is said to be valid if the questions on the questionnaire can reveal something that will be measured by the questionnaire. The reliability of a study refers to the degree of stability, consistency, predictive power, and accuracy. A questionnaire is said to be reliable if a person's answer to the statement is consistent or stable over time.

The test instruments used in this study were validity and reliability tests. A questionnaire is said to be valid if the questions on the questionnaire can reveal something that will be measured by the questionnaire. The reliability of a study refers to the degree of stability, consistency, predictive power, and accuracy. A questionnaire is said to be reliable if a person's answer to the statement is consistent or stable over time.

\section{RESULTS AND DISCUSSION}

In the distribution of online questionnaires, respondents collected in this study were as many as 55 respondents. Characteristics of respondents can be seen from gender, age, length of the investor, the portion of the investment, and investment considerations which can be seen in table 2. The classification is carried out on respondents to clearly and accurately determine the respondent as the object of this research which will be tested for validity and reliability. in research.

Table 1. Characteristics of Respondents

\begin{tabular}{lcc}
\hline $\begin{array}{c}\text { Respondent } \\
\text { Characteristics } \\
\text { Gender }\end{array}$ & Amount Percentage \\
\hline Male & 35 & $64 \%$ \\
Women & 20 & $36 \%$ \\
Age & 28 & $51 \%$ \\
17-25 years & 13 & $24 \%$ \\
$26-35$ years & 10 & $18 \%$ \\
$36-45$ years & 4 & $7 \%$ \\
$>45$ years & & \\
Old Investor & 37 & $67 \%$ \\
$<3$ years & 13 & $24 \%$ \\
$3-5$ years & 5 & $9 \%$ \\
$>5$ years & & \\
Investment Portion & 20 & $36 \%$ \\
$<10 \%$ & 17 & $31 \%$ \\
$10-17 \%$ & 8 & $15 \%$ \\
$18-25 \%$ & 10 & $18 \%$ \\
$>25 \%$ & & \\
Investment & & \\
Considerations & 12 & $22 \%$ \\
Period & & \\
Returm & 31 & $56 \%$ \\
Risk & 12 & $22 \%$ \\
\hline
\end{tabular}

Source: data that has been processed by the author (2020)

In table 1 we can see that most of the investors are young people who need to invest. Young people need to prepare for their old age by investing from an early age. Many of the investors are still new to the stock investment instrument. Stocks are a new investment that young people can enjoy now because the price is no longer expensive. For example, the capital market in Indonesia continues to develop quite rapidly. Data from the Financial Services Authority stated that investors in the Indonesian Capital Market increased significantly from last year's 22 percent. The share for investment in stocks for investors is still around $10 \%$ of their income. And most 
investors choose stocks as their investment because the return is quite high.

The variables in this study consist of Knowledge Management and Investor Behaviour. Each variable has 6 (six) indicators and questions. Through the respondents' answers that the researchers got, it can be seen the results of the outer model test for the SmartPLS calculation in the image below

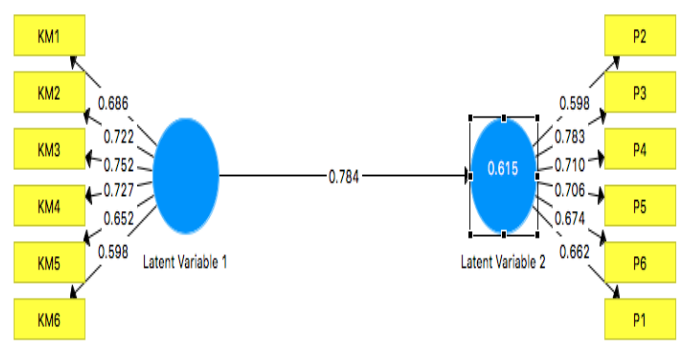

Figure 1. Outer Model Result

Source: output SmartPLS (2020)

The image above shows the values of 12 indicators from two variables. It can be seen that 10 indicators have a value of more than 0.60 while two indicators, namely $\mathrm{P} 2$ and KM6, have a value of less than 0.60 . Two indicators with a value below 0.60 do not qualify and should be removed.

Table 2. Reliability and Validity Test

\begin{tabular}{cccc}
\hline Var & CA & CR & AVE \\
\hline KM & 0.774 & 0.848 & 0.530 \\
PI & 0.766 & 0.843 & 0.519 \\
\hline
\end{tabular}

Source: Output SmartPLS (2020)

As required by (Ghozali, 2015) that the value of the calculation of Average Variance Extracted (AVE) is better if it has a value of more than 0.5 . The better Composite Reliability (CR) and Cronbach Alpha (CA) calculation values have a value of more than 0.6 . It can be seen from Table 2 that all the conditions have been met.
Table 3. Bootstrapping Test Results

\begin{tabular}{cccc}
\hline Var & $\begin{array}{c}\text { Std. } \\
\text { Deviation }\end{array}$ & $\begin{array}{c}\mathbf{T} \\
\text { statistic }\end{array}$ & $\begin{array}{c}\mathbf{P} \\
\text { Values }\end{array}$ \\
\hline $\mathrm{KM}$ & 0,460 & 16,542 & 0,000 \\
\hline \multicolumn{3}{c}{ Source: output SmartPLS $(2020)$}
\end{tabular}

Based on the bootstrapping results in table 3 , shows that the Knowledge Management hypothesis has a significant effect on accepted Investor Behaviour. This is evidenced by the $P$-value that is smaller than 0.05 or the $T$ statistic value that is greater than 1.92 .

Investor behaviour is a decision made by investors on their investment. The decision was based on investor rationality. A rational investor means using his ability to analyze the shares of companies listed on the Indonesia Stock Exchange. Rational investors plan, target, buy, sell, and hold shares based on six factors. Investors must first identify themselves. Knowledge about oneself (Knowledge Identification) is important so that investors can plan their decisions according to their profile. After knowing his profile, investors will learn all the information (Knowledge Acquisition) about the capital market to become knowledgeable and develop it (Knowledge Development) so that it continues to grow and be up to date. For this knowledge to continue to exist in investors, investors must store it (Knowledge Utilization) by sharing information (Knowledge Sharing and Distribution) with other investors. When investors can manage this knowledge (information), investors will demonstrate rational behaviour by deciding on investments based on information that is neutral, relevant, and according to investors' own needs.

The results of this study are in line with the research (Puspitaningtyas, 2013) which states that the process of making investment decisions requires accounting information that is presented in the company's financial statements. This information is useful for investors to estimate the value and risk of the company through financial statement 
analysis. The results of the analysis then form the basis for rational investors' decision making.

\section{CONCLUSION}

The conclusion that can be drawn from the discussion of this research is that Knowledge Management has a significant effect on Investor Behaviour. So better knowledge management will affect rational investment decisions.

\section{REFERENCES}

Agustin, P., \& Mawardi, I. (2014). Muslim Investor Behaviour in Stock Transaction in the Capital Market. Jestt, 1 (12), 874-892.

Armstrong, SJ, \& Mahmud, A. (2008). Experiential learning and the acquisition of managerial tacit knowledge. Academy of Management Learning and Education, 7 (2), 189-208. https://doi.org/10.5465/AMLE.200 8.32712617

Christanti, N., Ariany Mahastanti, L., \& Economics and Business, Satya Wacana Christian University, F. (2011). Factors That Investors Consider In Making Investments. Journal of Management Theory and Applied / Years, 4 (3), 37-51.

Ghozali, I. (2015). SmartPLS 3.0 (2nd ed.). Diponegoro University.

Hong, H., \& Stein, JC (1999). HongSteinjf-mom. The Journal of Finance, LIV (6).

Nofsinger, JR (2002). The Psychology Of Investing (sixth). Prentice-Hall.

Puspitaningtyas, Z., \& Jember, U. (2013). Investor behaviour in investing in the capital market. October, 0-19.

Rahimli, A. (2012). Knowledge Management and competitive advantage. liste, 2 (7), 37-43. http://www.iiste.org/Journals/inde x.php/IKM/article/view/3255

Shahzad, SJ. (2013). Behavioural Or Traditional Paradigm? Evidence From Karachi Stock Exchange (KSE) And Investor Community Of Pakistan. Interdisciplinary Journal Of Contemporary Research In Business, 4 (10), 605-619.

Veer Ramjeawon, P., \& Rowley, J. (2017). Knowledge management in higher education institutions: enablers and barriers in Mauritius. Learning Organization, 24 (5), 366-377. https://doi.org/10.1108/TLO-032017-0030 